\title{
Determinação e diferença: considerações sobre a razão suficiente segundo Leibniz
}

\author{
Nuno Ferro \\ nunovrferro@gmail.com \\ Universidade Nova de Lisboa, Lisboa, Portugal
}

resumo 0 artigo pretende analisar alguns dos aspectos da noção de razão e do significado de "dar razão", tal como Leibniz os entende, relacionando a noção de razão com outros conceitos igualmente fundamentais, como os de determinação e de diferença. A análise destas noções faz-se a partir da oposição de Leibniz à tradição da liberdade de indiferença, a partir de uma das suas fontes principais, os textos de Duns Escoto

palavras-chave determinação; diferença; existência; liberdade; razão; teodiceia

Entre os muitos textos em que Leibniz introduz e apresenta o princípio de razão suficiente está, como se sabe, o do parágrafo 7 dos Princípios da Natureza e da Graça. O texto diz:

Jusqu'icy nous n'avons parlé qu'en simples Physiciens: maintenant

il faut s'elever à la Metaphysique, en nous servant du Grand Principe, peu employé communement, qui porte que rien ne se fait sans raison suffisante, c'est à dire que rien n'arrive, sans qu'il soit possible à celuy qui connoitroit assés les choses, de rendre une Raison qui suffise pour determiner, pourquoy il en est ainsi, et non pas autrement. Ce principe posé, la premiere question qu'on a droit de faire, sera, Pourquoy il $y$ a plustôt quelque chose que rien? Car le rien est plus simple et plus facile que quelque chose. De plus, supposé que des choses doivent exister, il faut qu'on puisse rendre raison, pourquoy elles doivent exister ainsi, et non autrement" (LEIBNIZ, 1978a, 602). 
O texto é evidentemente muito denso e inclui uma enorme multiplicidade de aspectos que deveriam ser analisados, por exemplo, o pouco uso que se faz de um princípio que, todavia, está sempre presente em tudo o que pensamos e fazemos; o facto de ter de haver uma razão para haver algo e para haver o que há; o facto de o nada ser mais fácil do que o ente; que se entende, afinal, por razão, que é que queremos dizer quando dizemos que há razão para qualquer coisa; que é que a noção de suficiência acrescenta (ou não acrescenta) à noção de razão (isto é, uma razão insuficiente é, nalgum sentido do termo, ainda uma razão?), etc. O problema é, aliás, bem actual. D. Parfit, em On What Matters, escreve logo na primeira página do primeiro capítulo:

It is hard to explain the concept of reason, or what the phrase 'a reason' means. Facts give us reasons, we might say, when they count in favour of our having some attitude, or our acting in some way. But 'counts in favour of' means roughly 'gives a reason for'. Like some other fundamental concepts (...), the concept of a reason is indefinable in the sense that it cannot be helpfully explained merely by using words" (PARFIT, 2011, p. 31).

Ou seja, não é claro a que é que corresponde a noção de razão, e apesar de Parfit ignorar tranquilamente o que a tradição pensou sobre o assunto, pode valer a pena regressar a Leibniz, também porque Leibniz se vangloria com frequência de dizer que o princípio de razão suficiente é o seu princípio.

Para dar conta das teses de Leibniz sobre o assunto - que, evidentemente, apenas podem ser abordadas aqui de modo sumário - pode ser útil recorrer à questão mais geral, à questão da razão de ser das coisas, no seu todo, à razão do Universo. E recorrer a essa noção tal como Leibniz a encontrou, isto é, no âmbito de uma tradição, que era ainda a tradição escolástica. O problema da razão do ser das coisas no seu todo é habitualmente tratado por Leibniz como o problema do que ficou mais tarde chamado teodiceia, que é precisamente o problema da justificação do que se passa. Ora como se sabe, uma das questões que percorre do princípio até ao fim o livro que tem esse título, é a de saber se há ou não justiça em Deus. O propósito da análise dessa questão parece ser, entre outros, isentar Deus da responsabilidade pelo mal no mundo.Ver-se-á, mais adiante que é que isso implica, do ponto de vista da compreensão do ente enquanto 
tal, mas pode começar-se pela questão no seu modo mais imediato: a responsabilidade de Deus pelo que se passa no mundo. Pede-se desculpa pela excursão teológica que se segue, mas ela parece ser uma boa entrada para a exposição sumária de alguns dos problemas que estão em causa no princípio da razão suficiente.

O problema da teodiceia é muito antigo, perseguiu a humanidade durante séculos e recebeu muitas formulações. Aquela que assume em Leibniz é que, apesar de tudo o que possa ocorrer neste mundo, Deus é, em última análise, justo. Para além de justo é ainda outras coisas, mas para o presente propósito interessa apenas focar a própria justiça. À partida, dizer que Deus é justo - independentemente das dificuldades existenciais que se possam verificar nas pessoas concretas - não parece levantar problemas especulativos de maior. A justiça é uma perfeição, não se vislumbra, pelo menos de modo imediato, que inclua na sua própria noção, de modo intrínseco, estruturas próprias de finitude, e, nesse sentido, pode dizer-se de Deus. E, todavia, o problema é muito mais complexo. A doutrina tradicional sobre a justiça - que não é discutida na Teodiceia; para dizer verdade, a própria noção de justiça não parece ser aí examinada com profundidade - é, em geral, em traços largos, esta: a justiça consiste em dar a cada um o que lhe é devido, ou aquilo que é seu. Há, assim, na justiça, pelo menos duas determinações básicas: há um determinado bem e esse bem deve ser dado, é um bem devido. A noção difícil é evidentemente a de devido, ou melhor, a do seu correspondente no sujeito do bem a quem é devido - o direito. De facto, o direito parece ser a determinação original. Há, assim, dois momentos fundamentais: um bem e um direito. Parece que não é possível haver justiça sem estas duas condições. Poderia haver muitas outras coisas muito boas - magnificência, liberalidade, bondade, misericórdia, etc. - mas não justiça, no sentido estrito do termo. Parece, portanto, óbvio que, se assim é, a questão da justiça de Deus assume contornos mais intrincados e levanta objecções graves. Deus seria justo se e só se desse a cada um o bem que lhe é devido, devido a cada um, como é evidente, e não a Deus. Ora isso significa, em última análise, que os entes criados - ou, pelo menos, alguns deles - têm direitos sobre Deus e que Deus está, por isso, originariamente em dívida. E diz-se "originariamente" pela mesma razão pela qual se diz que Deus é originariamente justo, pelo menos segundo Leibniz ${ }^{1}$. De facto, Leibniz pretende precisamente mostrar que 
Deus não é justo "opcionalmente", como se pudesse não o ser, como se, vendo bem as coisas, não faltasse a nada se a justiça não lhe pudesse ser atribuída. A dizer verdade, uma espécie de justiça opcional não é pensável - a não ser como modo de falar impróprio -, porque ser justo é dar a alguém aquilo a que tem direito (que, portanto, de certo modo, já é seu) e alguém tem direito se realmente o tem, passe a redundância. É certo que se poderia pensar em direitos concedidos por um soberano magnânimo, quer dizer, poder-se-ia supor que Deus teria concedido direitos às criaturas, a algumas delas, mas que tais direitos não decorreriam da essência dessas criaturas, ser-lhes-iam totalmente estranhos e extrínsecos. Nesse caso, poderia haver liberalidade da parte de Deus, mas não, pelo menos em sentido rigoroso, justiça. Na verdade, se assim fosse, Deus teria uma espécie de justiça condicional, isto é, seria justo em virtude do seu bel-prazer, algo que precisamente não corresponde à justiça, pois a justiça requer sempre, parece, que o "outro" tenha algum poder real e não condicional sobre "mim". A admissão da possibilidade de direitos concedidos tornaria impossível a justiça ou a injustiça em Deus, pois Deus não seria justo ou injusto nem ao conceder tais direitos nem ao retirá-los ou a não lhes dar cumprimento. Ora a tese de Leibniz não é essa. Do seu ponto de vista, Deus é realmente justo. E é precisamente porque é justo que não lhe pode ser imputado o mal de que se sofre neste mundo, porque mal há certamente e é difícil imputá-lo à bondade. Mas isso parece implicar, portanto, que o ente criado, ou algum tipo dele, tenha direito a exigir de Deus um certo tipo de bens, aqueles que lhe correspondem e são devidos. Não se percebe, insiste-se, como é que Deus poderia ser justo fora destas condições. E, pelo contrário, percebe-se muito bem como é que poderia ser injusto nestas condições: quer recusando um bem devido quer concedendo um mal indevido. O problema de Leibniz é, como se sabe, principalmente o segundo, ainda que acabe por dar uma resposta surpreendente ao primeiro: Deus não só concede o bem devido como o bem devido exactamente enquanto devido - é o maior bem possível, o que não deixa de ser extraordinário, porque isso significa, de facto, que a justiça de Deus como que supera a sua infinita bondade. Deus não faz, por isso, mais do que Lhe corresponde, não faz mais do que Lhe compete produzindo o maior bem possível. Para dizer verdade, a tese de Leibniz é que Deus é, mais do que tudo, justo, e por isso dá a cada um aquilo que lhe é devido, 
tanto no bem quanto no mal. A conclusão é, assim, clara: Deus está, pelo menos de certo modo, condicionado a um certo dever.

Por razões de rigor, abre-se aqui um pequeno parêntesis, que parece necessário para evitar mal-entendidos. Quando aqui se afirma que Deus, porque é justo, está, de um modo ainda a determinar, submetido ao dever pretende apenas dizer-se que o ente finito deve ter algum direito sobre Deus. Mas não se pretende com isso sugerir que tal facto implique qualquer tipo de constrangimento em Deus, isto é, que o dever seja, no Seu caso, uma idealidade em relação à qual Ele se encontre a alguma distância, o que não parece fazer sentido e que o próprio Leibniz, com toda a tradição, resolutamente nega. $O$ dever, para Deus, não tem nenhum significado coercivo. Para usar a linguagem de Kant, a vontade de Deus é santa e por isso não está submetida a uma lei de que se diferencie. Como é óbvio, não há em Deus vontade patologicamente afectada. Mas parece que isso não anula o direito real do ente finito relativamente a Deus porque, se anular, desaparece imediatamente a noção de justiça e desaparece totalmente. De facto, repete-se, se o ente finito, nem que seja um único, estivesse privado, radicalmente privado de qualquer direito, não se vislumbra de que modo poderia haver injustiça em qualquer coisa que lhe ocorresse; ou justiça. É certo que a vontade de Deus é santa. É igualmente certo que mesmo o justo Job não tem direito a razões, mas, segundo Leibniz, Job pode estar tranquilo porque Deus é justo. Job pode não receber razões, mas não se pode queixar de ter sido privado de qualquer direito; se não recebeu razões, é porque não tinha direito a elas. Todavia, Job pode estar tranquilo, não porque não tenha direito a nada, mas porque todos os seus direitos estão satisfeitos. É possível que, do ponto de vista prático e empírico, o resultado de não ter direitos ou de os ter todos satisfeitos possa não ser muito diferente, mas a alteração conceptual é total. Num caso Deus é justo - o que tranquiliza Leibniz -, no outro não se sabe se o é.Assim, do ponto de vista de Leibniz, Deus não pode ser acusado da responsabilidade pelo mal, porque é justo. Como se vê, seria à partida possível pensar na possibilidade de Deus estar fora da oposição justo/injusto, como se nenhum dos termos lhe fosse aplicável ou atribuível. A justiça poderia ser uma determinação própria do ente finito, das relações intersubjectivas, da vida social, etc. Todavia, segundo Leibniz não é assim. E, por esse motivo, Leibniz ver-se-á obrigado a ter de explicar 
como é que Deus é Deus e, todavia, é também, de certo modo, sujeito de deveres, por muito paradoxal que isso possa parecer. Dizer, depois, que os cumpre será relativamente simples. Complexo é provar que há entre o ente finito e Deus uma relação de direitos e deveres. E essa tarefa é uma das que Leibniz enfrenta na Teodiceia.

Ora é sabido que, também neste aspecto, Leibniz faz parte de uma tradição antiga. O que se percebe bem. A questão da justiça de Deus, dadas as implicações e dificuldades teológicas que facilmente se adivinham, foi uma questão debatida com cuidado pela escolástica. E, como era próprio da escolástica, as soluções nem sempre foram unânimes, ainda que haja aspectos comuns a todas elas. Para a análise do problema em Leibniz interessa, por motivos que se tornarão claros já a seguir, acompanhar em traços muito gerais o ponto de vista de Duns Escoto e deixar de lado o de Tomás de Aquino ${ }^{2}$. É certo que Leibniz, na Teodiceia, raramente discute directamente com Duns Escoto, ainda que haja muitas referências às teses escotistas, que Leibniz, aliás, conhecia bem, o que não podia deixar de acontecer dada a quantidade de autores citados na Teodiceia. Mas apesar dessa relativa escassez de referências nominais, o ponto de vista de Duns Escoto - de que Leibniz, em geral, desconfia dizendo que "le subtil Scotus (...) obscurcit souvent les choses, au lieu de les eclaircir" (LEIBNIZ, 1978b, p. 329) - é particularmente elucidativo a este propósito, pois permite esclarecer e delinear com muito mais precisão a argumentação de Leibniz, as razões que o levaram a concluir o que de facto concluiu.

Duns Escoto trata explicitamente da questão da justiça de Deus na parte IV da Ordinatio, d. 46, q. 1, cujo título é precisamente "Utrum in Deo sit iustitia". E começa, como deve, por definir a noção de justiça. Com esse fito, recorre a S. Anselmo e define a justiça como uma certa rectitudo, que Duns Escoto define como rectitudo uoluntatis. A rectidão da vontade pode, por sua vez, ser considerada de dois modos: em primeiro lugar, a vontade pode ser recta por si mesma, isto é, ela pode ser, como se explicita no texto, inobliquabilis, impassível de ser torcida, e isso em virtude da sua própria natureza. Em segundo lugar, a vontade pode ser recta, porque pode observar uma rectitudo ad alterum, isto é, como parece ser claro, porque pode estar em conformidade com a lei, com uma ordenação da razão que lhe seja anterior. Para estabelecer um contraponto com Leibniz, parece claro que interessa tomar em consideração sobretudo o segundo 
caso, e, aplicando-o à justiça de Deus, tentar saber se a vontade de Deus está, de facto, conforme a algum tipo de ordenação quasi ad alterum, como que a qualquer coisa de outro, tese que é, como se sabe, a de Leibniz. Abreviando razões, porque não é possível expor aqui toda a argumentação, a conclusão de Duns Escoto é que, em certo sentido," voluntas divina non habeat rectitudinem inclinantem determinate ad aliquid, nisi ad suam bonitatem, quasi ad alterum, (nam ad quodcumque aliud obiectum mere contingenter se habet, ita quod aeque potest in hoc et in eius oppositum), sequitur quod nullam iustitiam habet, nisi reddendum suae bonitati vel voluntati, quod condecet" (DUNS ESCOTO, 2001) ${ }^{3}$. A tese parece ser relativamente inocente e estar em acordo total com a tradição. Parece, aliás, ser a única tese possível, pois qualquer outra introduziria em Deus um momento de finitude, na medida em que Deus seria devedor de outro precisamente enquanto outro diferente d'Ele, o que é impensável dada a transcendência de Deus e a sua infinitude. Neste sentido, tomada na sua literalidade, a tese pode encontrar-se em Tomás de Aquino ${ }^{4}$ e também em Leibniz. Quer dizer, para todos os autores, Deus só pode ser devedor de Si mesmo, no sentido rigoroso do termo, e isso decorre da própria noção de Deus. Duns Escoto, todavia, determina com mais precisão este "Si mesmo" de Deus, quer dizer, tenta circunscrever com mais rigor o que se entende por direitos e deveres imanentes a Deus. Deus é, diz, devedor à sua bondade e àquilo que é conveniente com a sua vontade. E não há quaisquer referências, no texto, à sabedoria de Deus ou à sua razão. E este é o ponto central da argumentação de Duns Escoto. O que não significa que não haja em Deus também uma certa justiça. De facto, segundo Duns Escoto, há. Há justiça em Deus porque Deus se encontra determinado por uma lei que é, de certo modo, prévia à sua vontade, lei que, todavia, não decorre minimamente da sua sabedoria, mas exclusivamente da sua bondade. Esta é, pois, a única justiça que há em Deus. Desta justiça de Deus, em sentido estrito, segue-se a única lei moral rigorosamente natural, aplicada a todas as criaturas, que não admite qualquer tipo de excepção, porque corresponde exactamente à justiça em Deus, a saber, Deus diligendum est. Assim, do ponto de vista legal, nada determina Deus a não ser a sua bondade e o que convém à sua vontade. $\mathrm{O}$ que significa ainda que a justiça que há em Deus introduz nEle como que uma determinação, determinação que produz uma inclinação - é o termo utilizado por Duns Escoto 
-, uma inclinação de Deus em ordem à sua bondade. Inclinação significa, portanto (e parece que não pode deixar de significar) ser determinado a partir de uma lei que constrange ou obriga a vontade, quer dizer, ordenação a algo quasi ad alterum. Ou seja, implica em última análise uma certa passividade, uma impossibilidade de controlar o movimento em ordem àquilo a que se está natural -e não livremente - inclinado. Inclinação parece, assim, significar, determinação passiva em virtude da natureza.

Imediatamente no seguimento do texto citado anteriormente, Duns Escoto acrescenta que o acto pelo qual a justiça de Deus $\mathrm{O}$ inclina, o acto que tem por objecto a Sua bondade, inclui muitos outros objectos secundários - que são os possíveis finitos - e isso é assim porque o intelecto divino, para além de ter o próprio Deus por objecto primário, considera também, e necessariamente, objectos secundários. Mas com uma diferença absoluta: o intelecto divino considera necessariamente os objectos secundários, mas a vontade estabelece com eles uma relação contingente. Uma vez mais, a tese parece banal, a tradição estará igualmente de acordo com ela e Leibniz repeti-lo-á sem cessar na Teodiceia. E, todavia, também uma vez mais, Duns Escoto está a introduzir uma distinção essencial que o obrigará a extrair uma conclusão que ofenderá radicalmente a delicada sensibilidade metafísica leibniziana. É mais curto e mais claro citar o texto: ad nullum obiectum secundarium ita determinate inclinatur voluntas divina per aliquid in ipsa, quod sibi repugnet, iuste inclinari ad oppositum illius, quia sine contradictione potest oppositum vele, ita potest iuste vele, alioquin posse absolute velle, et non iuste, quod est inconveniens" (DUNS ESCOTO, 2001, n. 27).

O texto é verdadeiramente central e diz, em traços largos, o seguinte: a inclinação da vontade de Deus tem por objecto a Sua própria bondade em si mesma considerada e de um modo exclusivo, isto é, fora da relação que inclui aos seus objectos secundários, fora, portanto, da relação ao ente finito criável. E isso é assim, porque, de outro modo, Deus poderia querer algo injustamente - isto é, contra uma inclinação da vontade afectada pela bondade e determinada pela razão -, e isso não pode ser possível. A tese não pode ser mais clara: se Deus tivesse alguma inclinação para os objectos secundários do Seu intelecto e da Sua vontade, ele poderia querer alguns injustamente. E isso é assim porque haveria objectos possíveis para além 
daqueles para os quais a vontade estaria justamente inclinada. Tais objectos são, por si mesmos, possíveis e, por isso, passíveis de serem objectos da vontade. Assim sendo, seria possível a vontade de Deus ser injusta, isto é, ir contra a determinação de uma certa lei que regularia a inclinação. Ora a vontade de Deus é justa por essência. Logo não há objectos possíveis contrários a objectos para os quais ela se inclina. Quer dizer, ela não se inclina para objecto nenhum. Duns Escoto joga aqui, como se vê, com três noções: a vontade (neste caso, a de Deus), os possíveis - que define de modo apenas formal, como aquilo que não é contraditório ${ }^{5}$ - e a inclinação da vontade, que é a determinação da vontade em ordem a algo em virtude de uma regra. A conclusão é, depois de confrontadas as três noções, que se houvesse inclinação na vontade de Deus para alguns dos possíveis, tornar-se-ia conceptualmente possível a injustiça de Deus, isto é, uma escolha contrária à inclinação da vontade justa de Deus. Por isso, Deus não pode, e não pode de maneira nenhuma, estar inclinado a um qualquer objecto secundário, seja ele qual for, possua a estrutura que possuir, pois isso é analiticamente contraditório com a noção de Deus. Tudo o que Deus pode escolher - isto é, tudo o que é não contraditório - é escolhido, se o for, justamente. Seja qual for o objecto, ele será escolhido, se o for, com justiça, e exactamente se passa a mesma coisa com todos os seus opostos, pois a justiça de Deus é pertença originária da vontade, ela é intrinsecamente recta fora de qualquer consideração de objectos secundários. A rectidão da vontade não depende da ordenação aos seus objectos, que podem variar infinitamente, permanecendo ela inalterável por essência. Noutros termos, Duns Escoto não admite a representabilidade de uma injustiça possível em Deus. Ora essa injustiça seria representável se Deus se inclinasse, em virtude da sua bondade, para alguns dos possíveis, pois haveria sempre a possibilidade dos opostos, que não está afectada por qualquer tipo de inclinação da vontade, dado que o seu ser possível lhes pertence em virtude da sua estrutura formal não contraditória. Logo, a diferença entre possíveis não tem qualquer significado para a vontade de Deus nem, portanto, para a sua justiça.É isso o que, na linguagem de Duns Escoto, significa dizer que a relação entre vontade e objecto secundário do intelecto divino é contingente. Ter uma relação contingente é, pois, pelo que fica visto até agora, não ter nenhum tipo de inclinação para o objecto com que se relaciona, ou, o que é a mesma coisa, ter uma relação 
absolutamente espontânea e activa, e não estar, de maneira nenhuma e sob nenhum ponto de vista possível, determinada por essa relação. A relação é contingente quando ela própria está totalmente sob o poder do seu sujeito e absolutamente em nada determinada pelo objecto.

É certo que uma mente conciliadora poderia pensar que, dada a Sua bondade, Deus nunca escolheria possíveis diferentes daqueles para os quais a sua bondade $\mathrm{O}$ inclina. Mas isso seria justamente admitir a possibilidade - a possibilidade metafisica - de Deus ser mau, injusto, vingativo, cruel, despótico, etc., Moloch, enfim. Que felizmente não o é, mas nada O impede de o ser. A injustiça de Deus seria perfeitamente representável, como se disse. Ora é exactamente isso que Duns Escoto quer excluir de modo radical. E a sua conclusão, por muito paradoxal que possa parecer, é que a justiça de Deus não pode dizer respeito ao seu objecto, isto é, só pode ser pensada, só pode ser representada, atribuindo-a originariamente à vontade, com total independência do seu objecto secundário eventual. Deus é, segundo Duns Escoto, metafisicamente justo, de tal modo que ser injusto é um predicado contraditório. $\mathrm{O}$ que não significa que todos os possíveis são "bons", o que seria uma escapatória. A tese de Duns Escoto é bem mais radical. No sentido rigoroso do termo, só Deus é bom e, por isso mesmo, precisamente por isso mesmo, não pode estar inclinado para mais nada, absolutamente para mais nada. Daqui decorre também, e inevitavelmente, a tese bem conhecida de Duns Escoto segundo a qual toda a bondade moral tem a sua origem na vontade divina, com a excepção do Deus diligendum est. Mas o que importava indicar, para a questão em análise é que, dito de um modo simples, tudo o que pode ser feito por Deus - isto é, todo o âmbito do possível - é justo em virtude da sua origem e não em virtude do seu objecto. E é assim a priori. A justiça de Deus não tem, pois, segundo Duns Escoto, nada que ver com inclinações da razão ou com a sabedoria do intelecto, porque isso implicaria sempre restrição imposta a Deus por objectos secundários. E a conclusão, também neste caso, parece óbvia: exceptuando um único caso - muito peculiar, aliás - a vontade de Deus não está dependente de nenhuma lei ou ordenação racional, seja ela de que tipo for. Não há, pois, nem pode haver, da parte de Deus, nenhum tipo de inclinação da vontade para os possíveis. O que significa, e Duns Escoto também o diz, que os possíveis não têm, em si mesmos, nenhum significado prático para Deus, quer dizer, não são 
considerados pelo Seu intelecto como algo "a ser feito". Duns Escoto é explícito a este respeito. Entre os seus textos, há uma curiosa questão que tem por título "Utrum Scientia Dei Respectum Factibilium Sit Practica" e a sua resposta (d. 38, q. un), é inequívoca: "intellectus divinus ex necessitate naturae est speculativus, et non est ad hoc formaliter libertas, licet non sit sine voluntate complacente" (DUNS ESCOTO, 1966). Quer dizer, os possíveis estão relativamente ao intelecto divino fora de qualquer pressão para a sua execução, de modo que estão presentes para Deus em modo neutro, como Duns Escoto também diz neutralidade existencial. Não têm, por isso, nenhum significado prático, quer dizer, não são vistos como "entes a realizar". Assim, a independência de Deus relativamente aos possíveis é ainda acrescentada estruturalmente e é exactamente isso que significa dizer que o intelecto de Deus é, por necessidade natural, essencialmente especulativo. De facto, dizer que um intelecto é especulativo é dizer que o sujeito de tal intelecto não está essencialmente interessado nos seus objectos - ou que não está, pelo menos, essencialmente interessado na execução dos seus objectos -, que são, portanto, para ele, termos de mera consideração ou contemplação. É também isso que significa dizer que a relação da vontade aos possíveis é meramente contingente. É fácil também perceber que é que isso significa. Significa que não há nenhuma razão para a existência do que quer que seja. De facto, é isso mesmo que Duns Escoto está a dizer, a saber, a negar expressamente a existência de um princípio como o da razão suficiente. A existência das coisas não decorre, pois, do intelecto divino, porque este é meramente especulativo e a existência dos entes finitos corresponde, em última análise, à realização prática de qualquer coisa. Nos possíveis não há, pois, qualquer indicação do seu “vir a ser”, enquanto tal, não há neles nada que mostre ou dê sinal que a existência lhes convém. Eles são, como se disse, totalmente neutros quanto à existência, não dizem respeito a ela na sua própria estrutura. É certo que um possível é algo que pode ser, por definição, mas por algum motivo Duns Escoto prefere a definição da possibilidade como ausência interna de contradição, pois dessa forma fica mais clara a sua neutralidade existencial. Não há, pois, como se disse, razão alguma para que um possível venha à existência, o que é outro modo de dizer que o decreto mediante o qual as coisas em geral passam a ser - e o decreto mediante o qual estas coisas passam a ser - deriva totalmente da 
vontade e não está regido pela razão. Assim, a escolha pela qual Deus decide que algo exista e que seja isto não pode provir, de maneira nenhuma, do intelecto, porque isso implicaria dar ao intelecto uma natureza prática, que é outro modo de dizer que Deus estaria interessado - no sentido técnico do termo - noutra coisa que não nEle, o que para Duns Escoto é absolutamente incompatível com a infinitude divina. Quer dizer, se Deus estivesse interessado nos possíveis, ou estes seriam necessários ou Deus poderia ir contra o preceito do intelecto e, assim possuir uma vontade má, porque o preceito do intelecto só pode ser recto ${ }^{7}$. Segue-se também daqui que a origem da contingência está na natureza especulativa do intelecto divino, quer dizer, depende de uma relação indeterminada da vontade aos possíveis, com uma liberdade de total indiferença relativamente a todos os opostos possíveis. A origem da contingência das coisas está, desta forma, na exclusiva natureza própria da sua causa: as coisas existem sem qualquer preferência intrínseca em relação à sua não existência, porque a vontade de Deus não admite constrangimentos de ordem alguma. Quer dizer, exclui-se totalmente a fundamentação objectiva da preferência. A contingência do existente é, assim, radical, pelo facto de existir em virtude de um decreto da pura vontade, e não admite, como se disse, justificação racional. Deve ter-se em conta, porque se trata de um aspecto central na análise de Leibniz, que para Duns Escoto há contingência na relação entre vontade de Deus e possíveis só porque há indeterminação da vontade, de tal modo que qualquer tipo de determinação implica analiticamente redução da contingência. É também óbvio que, com isso, Duns Escoto assegura naturalmente tanto a liberdade de Deus como, do seu ponto de vista, a sua justiça.

Para terminar este breve esboço de algumas das teses de Duns Escoto, conviria recordar o que se disse anteriormente. Duns Escoto é levado a afirmar a total liberdade de Deus e a radical contingência da realidade - isto é, a indiferença relativamente aos possíveis - entre outros motivos para salvaguardar a intrínseca justiça de Deus. Se há teodiceia é certamente a do pensamento de Duns Escoto. A sua teodiceia passa por tentar encontrar um modelo conceptual, não para o facto de Deus ter escolhido bem ou justamente, no sentido em que usualmente entendemos essas expressões, isto é, determinando o substantivo com o adjectivo ou o advérbio - porque isso faria de Deus, em qualquer dos casos, um ente finito 
-, mas ligando analiticamente escolha (isto é, vontade) e justiça; como ele diz, pensando uma iustitia inobliquabilis. Isso tem o seu preço: Deus não é justo porque faz o que devia fazer, mas sim porque, em sentido rigoroso, não devia fazer absolutamente nada e, sendo Quem é, faça o que fizer, só o pode fazer justamente. Duns Escoto tem sido acusado de muitas coisas, de todo o tipo de irracionalismos e arbitrários voluntarismos. Mas de modo nenhum não se pode dizer dele que não teve em conta a causa Dei ou que não foi rigoroso e consequente na defesa dessa causa.

Ora como se sabe a compreensão que Leibniz tem do que se passa é, não só diferente, mas, por assim dizer, exactamente simétrica, ponto por ponto, da de Duns Escoto. Todo este conjunto de teses e de argumentos é virado do avesso por Leibniz. E interessa em primeiro lugar verificar porquê. Num primeiro momento, o interesse de Leibniz parece ser também o da causa Dei. De facto, as análises de Duns Escoto fazem de Deus um ser sem regra nem razão, indiferente a qualquer tipo de sabedoria ou racionalidade, nem sequer - relativamente às escolhas que realizam a existência - as suas próprias. Deus agiria, portanto, de um modo arbitrário, tanto lhe fazendo produzir uma coisa ou a contrária ou nenhuma, quer dizer, Deus pareceria ser o domínio do caprichoso; seria, afinal, como Leibniz repete, uma espécie de omnipotência irresponsável, um despotismo em nada iluminado, do qual tudo - precisamente tudo - se poderia esperar; um Deus que apenas estaria condicionado por uma vontade cuja relação ao seu objecto seria radicalmente contingente, o que, do ponto de vista de Duns Escoto, significa indiferente e desinteressado, e de tal modo que não apenas os possíveis seriam contingentes como também a própria relação aos possíveis (que dificilmente será diferente do próprio Deus) seria contingente: o reino do caos e do acaso. É certo que Duns Escoto poderia dizer - como efectivamente diz - que se deve ter em conta a bondade de Deus. Mas, do ponto de vista leibniziano, tal tipo de réplica é totalmente insignificante, porque a bondade de Deus não tem, no que diz respeito à sua relação com as criaturas, nenhum tipo de regra quando considerada isoladamente. Na verdade, tal como, segundo Escoto, Deus é justo em qualquer dos casos, poder-se-á dizer que terá de ser bom em qualquer dos casos, relativamente a todos os opostos, mas é óbvio que essas bondade e justiça são insignificantes, precisamente porque se aplicam a todos os opostos, quer dizer, não acalmam a razão, não esclarecem nada, 
não produzem efectivamente qualquer tipo de sentido. A bondade de Deus não é, por isso, segundo Leibniz, de confiar. Convém que haja uma qualquer regra ou lei. De facto, Deus faz e fez coisas boas, mas podia perfeitamente fazer outras totalmente diferentes, que para nós, por hipótese, talvez pudessem ser menos boas ou mesmo péssimas, e isso, como se disse, deixa a razão em sobressalto e em completa indeterminação, sem saber o que pensar. Uma potência caprichosa - quer dizer, não determinada pela intrínseca racionalidade do seu objecto - por muito boa que seja não é, como se disse, de confiar. Por esse motivo, Leibniz rejeita expressamente uma justiça em Deus que tenha a vontade por regra ${ }^{8}$.

Tal tipo de argumentação encontra-se, como se sabe, espalhada ao longo da obra de Leibniz ${ }^{9}$. E, todavia, o que parece estar, em última instância, sob foco da análise não é somente a justificação do comportamento aparentemente insondável de Deus, entre outras coisas porque nada assegura que estejamos em condições de justificar o Omnisciente, ou que tal nos seja pedido. O que parece estar em causa na retórica leibniziana por oposição às teses de Duns Escoto é o facto de, segundo Leibniz, as teses deste tornarem a totalidade da existência absolutamente insignificante, de todos os pontos de vista, tanto metafísico como ético. Quer dizer, o que parece verdadeiramente preocupar Leibniz não é apenas a boa-fé de Deus, não é somente uma questão de teodiceia, como ficou a chamar-se, ainda que presumivelmente tal preocupação esteja também no seu horizonte. Mas o centro da atenção leibniziana é o facto de as teses que fazem da vontade (neste caso, a de Deus) a origem e o sentido da contingência, da existência e desta existência, do todo da realidade, implicarem, em última instância, um nihilismo radical. É precisamente isso que Leibniz combate com energia. $\mathrm{O}$ que se comprova com evidência quando, por exemplo, se repara que no centro da análise de Leibniz na Teodiceia está a crítica à noção de liberdade de indiferença que, como se sabe, depende de modo muito significativo de Duns Escoto, ainda que não exclusivamente. O problema da liberdade de indiferença é, como se sabe, o da origem da determinação: de onde vem uma dada determinação? Ou, o que é a mesma coisa, que é, de facto, determinar ou ser determinado? A tese da liberdade de indiferença defende que o sujeito está perante os contrários que lhe são apresentados numa situação de incontaminação, por assim dizer, quer dizer, os vários objectos que tem perante si não estão constituídos em forma de peso ou 
valor. Pelo contrário, o sujeito tem relativamente aos objectos uma relação especulativa, o que não significa que não possa estar perante um problema prático. Dizer que a atitude do sujeito é especulativa corresponde a dizer que o significado dos opostos é exactamente equivalente, todos valem precisamente o mesmo, de tal modo que o sujeito não sofre mais pressão por parte de um do que de qualquer outro. E essa equivalência não corresponde a um qualquer valor igual de todos - que seria este ou aquele -, o que Leibniz também nega, ainda que por outras razões. Quer dizer, a equivalência dos objectos, no modo como a tese da liberdade de indiferença a compreende, não corresponde ao problema do burro de Buridan, em que os objectos convocam, de facto, o sujeito, só que de modo exactamente igual. Mas não é esse o problema aqui, pois o problema do burro de Buridan não é o da liberdade de indiferença. O burro não é indiferente aos contrários; o problema do burro é que os contrários são indiscerníveis, o que é um problema complexo quando se trata de escolher um de entre eles. Pelo contrário, numa liberdade de indiferença os objectos a escolher são, relativamente ao sujeito que os tem de escolher, totalmente neutros, como dizia com exactidão Duns Escoto. O que se percebe: a tese da neutralidade dos possíveis para o intelecto divino aplica-se à relação de todo o tipo de posições perante um qualquer intelecto, inclusive quando se trata de um intelecto prático: todos os contrários têm o mesmo peso, a saber, nenhum. É precisamente por isso que o sujeito lhes pode ser indiferente. No limite, o sujeito poderia até encontrar-se em completa indiferença entre objectos apresentados como bons ou como maus, não estar mais inclinado para uns do que para outros, e é bem sabido que também esta tese encontrou quem a defendesse. Não era a tese de Duns Escoto, mas parece ser a de Ockham: "voco libertatem potestatem qua possum indifferenter et contingenter diversa ponere, ita quod possum eumdem effectum causare et non causare, nulla diversitate existente alibi extra illam potentiam" $\left(\right.$ OCKHAM, 1980) ${ }^{10}$. Os defensores da liberdade de indiferença, como se vê, dizem que só há liberdade se houver indiferença, de tal forma que esta é uma determinação essencial daquela. E a razão parece clara: se assim não fosse, isto é, se o objecto fosse determinante na escolha, o sujeito seria passivo, seria dominado por um poder alheio, não teria qualquer controlo sobre a relação ao seu objecto, tudo determinações que nós pensamos fazerem parte da noção de liberdade. 
Ora todo este tipo de argumentação repugna claramente a Leibniz. De facto, o problema coloca-se, para ele, do seguinte modo: toda a escolha implica a eliminação da neutralidade - há um possível que é escolhido e todos os outros são preteridos, postos de parte. Isso significa, como é claro, que se $p \hat{s}$ algo, que se escolheu qualquer coisa diferente do oposto. Quer dizer, passou a haver algo que ocupa espaço metafísico no âmbito das coisas que são, qualquer coisa que não era e que agora é, que transitou do possível para o real, passando a ser. Isto é, passou a haver algo de determinado. Noutros termos, enquanto todos os possíveis coexistem na possibilidade e não se atravancam, pois todos podem perfeitamente ser e enquanto podem ser não se incomodam no espaço da possibilidade, isso não ocorre na realidade. Pelo contrário, é precisamente essa coexistência dos possíveis que ficou excluída, e é essa exclusão que significa determinação. Quanto à determinação, todos os possíveis enquanto possíveis são indeterminados, pois a determinação de um não impede a de outro, dado que tal determinação é somente possível. Ora determinar é exactamente excluir o oposto, que é o que o possível não faz. E o que preocupa Leibniz é exactamente aquilo que leva a excluir o oposto, isto é, a pôr a determinação, a eliminar a aparente neutralidade dos possíveis. E Leibniz defende, como se sabe, que é totalmente impossível que este processo venha só da vontade, quer dizer, é impossível que o processo de eliminação de contrários tenha como origem a neutralidade dos contrários. É impossível e não apenas de facto; é, na verdade, totalmente irrepresentável. E isto por várias razões. Assim, em primeiro lugar, dizer que a constituição da determinação é produzida pela vontade não é dizer que ela tem a sua origem, por exemplo, num capricho. É, muito mais claramente, dizer que não tem origem nenhuma. A eliminação da pressuposta neutralidade pela vontade corresponderia a estabelecer o nada como fonte da determinação. $\mathrm{Na}$ verdade, se, do ponto de vista da determinação, todas as coisas são radical e originalmente iguais e se o sujeito que tem de escolher uma delas está em situação de total neutralidade e indiferença relativamente a todas, isso implica necessariamente que a posição da diferença - quer dizer, a origem da preferência que fará que uma seja posta em detrimento de todas as outras - não tenha qualquer origem identificável. A diferença não pode vir da vontade porque ela está, na hipótese em consideração, em estado de indiferença relativamente a todos os opostos. A origem também não pode provir da diferença entre os 
possíveis, porque estes são apresentados à vontade em estado de neutralidade, quer dizer, são para a vontade independentemente das diferenças de conteúdo que evidentemente possuem, ou seja, a sua diferença é indiferente para a vontade. Assim, é de certo modo evidente que a origem da determinação não pode provir da vontade porque a vontade que escolhe é sempre a mesma seja qual for a escolha e, assim, a determinação própria da escolha, isto é, aquilo mesmo que é diferente, não pode vir dela, porque ela é, na hipótese, idêntica em todas as diferenças. Dito de outro modo, se a vontade não tem " $x$ " em consideração quando escolhe de facto " $x$ ", então não é, na verdade, " $x$ " que é escolhido, pois o seu ser " $x$ " em nada contribuiu para a sua própria escolha. Não se escolhe " $x$ ", enquanto tal, quando a razão pela qual ele é escolhido é exactamente a mesma que quando se escolhe "y". Em qualquer dos casos, a escolha é totalmente indeterminada, isto é, não há, no sentido rigoroso do termo, qualquer escolha. Ou seja, Leibniz diz que a tese da liberdade de indiferença não tem em vista (e não tem de modo absoluto) o termo ou objecto da sua escolha quando escolhe. $\mathrm{O}$ que não significa, insiste-se, que escolha cegamente, porque na escolha caprichosa há ainda uma inclinação para escolher, pelo menos essa inclinação. Ora aqui não há nenhuma diferença, nem para escolher, nem para escolher isto ou aquilo. O que significa que se oferece o nada como explicação da determinação. Todo o problema está, pois, na origem da diferença. E está porque a liberdade de indiferença nega a existência de diferenças que tornam possível a escolha, diferenças que são a esse respeito, significativas, quer dizer, nega a natureza operativa de um termo que Leibniz repete continuamente a este propósito: o termo latino potius, que indica exactamente preferência. A negação do potius significa, portanto, a exacta identidade do diferente, não numa dialéctica mais profunda, mas na total indistinção do totalmente neutro. Quer dizer, significa, como se disse, pôr o nada como origem. Assim, do ponto de vista leibniziano não se trata de acusar a tese da liberdade de indiferença de irresponsabilidade ou de capricho despótico e cego. Trata-se, simplesmente, de dizer que ela é irrepresentável, uma expressão sem qualquer significado, ou, como Leibniz gosta de repetir na Teodiceia, que se trata de uma mera quimera (LEIBNIZ, 1978b, p. 129, 219, 297, 303, 306), uma fantasia insignificante, um nome que não diz nem corresponde a nada, porque equivale a pressupor que uma coisa surge de coisa nenhuma:"vouloir qu'une determination vienne 
d'une pleine indifference absolument indeterminée, est vouloir qu'elle vienne naturellement de rien" (LEIBNIZ, 1978b, p. 306). E surgiria de coisa nenhuma, não porque não houvesse um ente anterior que fosse a sua causa eficiente - o que os defensores da liberdade de indiferença evidentemente admitem: precisamente a vontade -, mas sim porque o seu surgimento não teria em conta a própria possibilidade da coisa a surgir, a fazer ser, o que é claro quando se recorda que, na tradição de Duns Escoto, a natureza da possibilidade é definida de modo apenas negativo. Trata-se, assim, de um caso muito mais grave e mais dificil de pensar que o da criação ex nihilo. A criação ex nihilo, independentemente da sua representabilidade para nós, afirma que a posição de qualquer coisa não deriva de um movimento, no sentido rigoroso do termo. Mas admite a anterioridade lógica da possibilidade do ente a constituir dessa forma e admite a relevância dessa possibilidade. Quer dizer, a criação pressupõe a sua possibilidade e tem-na em conta, na medida em que o ente criado é-o em virtude da sua possibilidade, que exclui a contrária. Pelo contrário, a tese da liberdade de indiferença afirma algo impensável, porque corresponde à posição de qualquer coisa que parece determinada, na medida em que exclui, pela sua bruta facticidade, o oposto, mas que efectivamente não é determinada, porque não exclui realmente o oposto, na medida em que a oposição não é tomada em consideração na posição do termo que, de facto, foi posto. Assim, segundo Leibniz, algo é determinado, não somente quando é facto, mas sim quando a sua posição exclui o contrário possível, o que significa que a possibilidade deve fazer parte da noção de determinação. Dito de outro modo, Leibniz indica claramente que a pura facticidade, tomada em si mesma, considerada fora da sua possibilidade e da contrariedade entre possíveis, é, na verdade, pura indeterminação, e isso é assim porque o contrário não tem, para a facticidade, qualquer significado. A pura e bruta facticidade é, pois, uma abstracção vazia, sem qualquer forma de conteúdo. E fazer do termo da decisão da liberdade de indiferença um puro facto é fazer que a liberdade tenha por termo uma abstracção vazia, o que não é, como se disse, coisa nenhuma.

Para poder examinar este assunto com mais rigor, e para tentar indicar que a questão com que Leibniz se debate não é, essencialmente, a da liberdade e a da estrutura da decisão, mas sim uma questão fundamentalmente ontológica, é necessário expor brevemente alguns aspectos do sentido do princípio de razão suficiente (prs). 
O prs está relacionado, de um modo nem sempre claro, com a estrutura formal do sentido "verdade". Nalguns textos, Leibniz praticamente identifica o prs com a "razão da verdade", com o sentido que constitui uma verdade como tal.Veja-se, por exemplo: "principium ratiocinandi fundamentale est, nihil esse sine ratione, vel ut rem distinctius explicemus, nullam esse veritatem, cui ratio non subsit. Ratio enim veritatis consistit in nexu praedicati cum subjecto, seu ut praedicatum subjecto insit" (LEIBNIZ, 1961, p. 11).

Uma proposição é verdadeira se o predicado inere no sujeito de tal forma que a inerência constitui o "ser verdade" de uma proposição. Como se tentará indicar brevemente a seguir, dizer que há uma razão para que uma verdade seja tal significa somente que "há verdade". Assim sendo, do sentido verdade deriva a regra formal que afirma que perante qualquer estado de coisas é possível dar razão dele. Por este motivo, Leibniz noutros textos faz explicitamente derivar o prs da noção de verdade assim entendida, como conexão entre sujeito e predicado: "vera autem propositio est cujus praedicatum continetur in subjecto, vel generalius cujus consequens continetur in antecedente, ac proinde necesse est quandam inter notiones terminorum esse connexionem, sive fundamentum $<$ dari $>$ a parte rei ex quo ratio propositionis reddi, seu probatio a priori inveniri possit (...). Ex his sequitur Axioma maximi Usus (...): Nihil evenire cujus ratio reddi non possit, cur sic potius quam aliter contigerit" (LEIBNIZ, 1961, p. 401-402). E, no mesmo sentido:"semper igitur praedicatum seu consequens inest subjecto seu antecedenti. et in hoc ipso consistit natura veritatis in universum seu connexio inter terminos enuntiationis, ut etiam Aristoteles observavit. (...) Statim enim hinc nascitur axioma receptum nihil esse sine ratione, seu nullum effectum esse absque causa" (LEIBNIZ, 1961, p. 518-519).

Independentemente da relação que o prs mantém com a noção de verdade, parece claro que não se trata de uma dedução da noção, mas, talvez mais propriamente, da formulação lógica (e operativa) do que está em causa no ser da verdade. Nesse sentido, parece ser necessário expor muito brevemente o sentido da natureza da verdade tal como Leibniz o apresenta. Para isso, pode ajudar aproveitar a referência que Leibniz faz a Aristóteles. Na análise do princípio de contradição no livro $\Gamma$ da Metafísica (1005b18 e ss), Aristóteles mostra que o princípio de contradição é uma pressuposição fundamental de qualquer afirmação com sentido, de tal 
forma que basta que aquele que o nega diga qualquer coisa para, por isso mesmo, aceitar a sua validade (1005b35 e ss). Quer dizer, faz parte do sentido de uma proposição a diferença relativamente ao seu contrário, de tal modo que com isso se manifesta que a diferença entre ser e não ser é significativa. Por essa mesma razão, Aristóteles estabelece uma conexão entre o sentido "verdade" e o princípio de contradição. Faz parte do sentido das proposições (isto é, o facto de possuírem um valor de verdade) que a contrariedade seja significativa, pois de outra forma dir-se-ia precisamente a mesma coisa ao afirmar proposições cujo conteúdo é contraditório; isto é, não se diria nada. Desta forma, o sentido "verdade" deriva do princípio de contradição, do facto de "ser assim" ser diferente de "não ser assim”. Ao termo "ser" corresponde um sentido, que é a base do sentido "verdade".

Já se indicou que a escolha tem de estar baseada na diferença. Mas é necessário vincar agora o fundamento da constituição da própria diferença. $\mathrm{E}$ o que parece mais ou menos claro é que, para que a diferença de posições seja significativa não basta o simples facto de haver uma e não outra, porque o simples facto é indiferente à posição da determinação enquanto tal, ao sentido da determinação: se algo está presente numa forma de presença que não exclui, a não ser pela sua presença fáctica, a possibilidade da presença do oposto, tal significa que a forma da presença posta é realmente insignificante: a posição dada está presente num modo de posição que é totalmente irrelevante e insignificante. Quer dizer: se algo é X do mesmo modo e pelo mesmo sentido que podia indiferentemente serY, o seu ser X em nada o determina, nada significa para ele, de tal forma que a proposição que afirma $\mathrm{X}$ desse algo não diz realmente nada dele, visto que o sentido mediante o qual "X é" é precisamente o mesmo que "X não é". Ou seja, se X se diz de um sujeito, é necessário que o sujeito se constitua, se torne a si mesmo presente mediante esse X, e só assim se diz dele. De outro modo o "dizer de" (que é próprio da verdade) não teria qualquer significado. Noutros termos: se $\mathrm{X}$ é diferente de $\mathrm{Y}$, haverá significação na diferença se, ao haver $X$, houver algum sentido para que tal ocorra. Se assim não fosse, quer dizer, se a ocorrência de $\mathrm{X}$ ou de $\mathrm{Y}$ for indiferente, o sentido da diferença entre eles está negado. É por essa razão, parece, que um dos momentos fundamentais do prs reside na noção, a que Duns Escoto recusava significado objectivo, de potius (de preferência a, antes de que): nihil evenire cujus ratio reddi non possit, cur sic potius quam aliter contigerit. $\mathrm{O}$ acontecimento de 
uma coisa inclui, pelo sentido do princípio de contradição, a diferença como fundamento da noção de "preferência". X ocorre de preferência a Y, porque X não é Y. E X é X também porque exclui a possibilidade de ser Y. Se assim não fosse, não haveria sentido nenhum na presença dessa determinação por oposição a qualquer outra possível e o seu acontecimento seria absurdo, no sentido estrito do termo, visto que a oposição perderia significado enquanto oposição. Ou seja, o prs deriva da diferença entre "ser" e "não ser", na medida em que essa diferença compreende um sentido (uma razão), e não é puramente fáctica: a sua redução à pura facticidade seria precisamente a sua anulação como diferença.Veja-se o seguinte dialogo da Confessio Philosophi:"TH: Nonne ante omnia concedis, nihil esse sine ratione? $\mathrm{PH}$ : Hoc ego adeo concedo, ut demonstrari posse putem nunquam existere quicquam, quin possibile sit (saltem omniscio) assignare rationem sufficientem cur sic potius quam non sit, et sic potius quam aliter sic. Hoc qui negat, evertit discrimen inter <ipsum> esse, et non esse" (LEIBNIZ, 1981, p. 118; o sublinhado é meu).

Ora a preferência da ocorrência das coisas que acontecem não pode derivar de um sentido que seja estranho às coisas, mas da sua própria identidade. Assim, o sentido do princípio de razão suficiente não pretende apenas expor o fundamento de uma escolha, mas sim o da própria possibilidade ontológica de constituição de um ente determinado, passe a redundância. De facto, se se diz de um sujeito que é, por exemplo, castanho, o seu ser castanho é preferível a "ser amarelo", não por questão de gosto, mas porque se trata de uma determinação que pertence realmente ao sujeito em causa. E essa pertença é pensada por Leibniz como conexão: deve haver alguma conexão entre a identidade do sujeito e a do predicado, pois, se assim não fosse o facto desse sujeito ter esse predicado ser-lhe-ia indiferente; e, por este motivo, a proposição que afirma que tal predicado é dele não seria verdadeira, porque não se estabeleceria nenhuma contrariedade (também não seria falsa, pelo mesmo motivo). De facto se o sujeito é castanho, como poderia ser amarelo, e poderia ser amarelo tal como poderia não ter cor alguma, qualquer proposição que se refira à eventual cor que facticamente ele tem deixaria o sujeito incólume, pois ele permaneceria intocado pela "determinação" que, apesar de tudo, se diz dele. Se algo se diz de um sujeito, deve encontrar-se na identidade do sujeito o sentido do que se diz dele, para que a proposição seja verdadeira (ou falsa). Só 
assim, o sujeito é o que se diz dele. Logo, há uma conexão entre sujeito e predicado (como é fácil de ver, o prs, pela sua relação com a natureza da verdade, possui também uma relação muito estreita com o princípio de contradição - e com o de identidade -, o que levanta vários e graves problemas, com os quais Leibniz se debateu. Não é possível fazer aqui o estudo da relação entre os três princípios. Em qualquer dos casos, é claro que Leibniz reconheceu que quer o princípio de contradição quer o prs derivam ou estão compreendidos na noção de verdade: "on peut dire en quelque façon que ces deux principes sont renfermés dans la definition du Vray et du Faux" (LEIBNIZ, 1978b, p. 414).

De aqui derivam muitas consequências, de entre as quais apenas se indicarão duas (que estão obviamente relacionadas). A primeira é a explicitação da noção de razão. Por razão ou fundamento Leibniz entende, como se viu, conexão. Apresentar a razão de qualquer coisa é mostrar de que modo tal coisa está conectada com uma identidade ou, no sentido inverso, de que modo tal coisa deriva dessa identidade. E só assim haverá resposta à pergunta "porquêe?" É claro que é esta natureza da razão que sustenta a possibilidade e o sentido de qualquer interrogação: não se responde à pergunta que interroga o "porquê" de um facto afirmando o próprio facto, como é evidente, pois é ele que está em causa. De aqui decorre a definição de razão que Leibniz apresenta habitualmente e também o facto de o prs ser "Principium ratiocinandi fundamentale".

Em segundo lugar, a natureza da razão implica a possibilidade de justificação a priori de todos os factos, ou seja, da redução, de iure, de toda a facticidade. Na verdade, a razão, no sentido técnico exposto, é precisamente a redução da facticidade: mediante a conexão com uma identidade, isto é, revelando o modo como um dado acontecimento deriva de uma identidade, anula-se o seu simples acontecimento imediato, passado ele a ser considerado a partir da sua origem. Haverá razão de um acontecimento quando a sua presença fáctica for substituída pela sua redução a uma identidade ideal (à sua possibilidade, portanto). É, aliás, esse o procedimento das ciências: unificar numa lei ou numa hipótese (num conteúdo ideal) uma pluralidade de factos, de tal forma que tal pluralidade não só se unifica como perde a sua facticidade, pois pode ser deduzida desse conteúdo ideal. Enquanto houver facticidade, há uma zona de não sentido, de pura imposição incompreensível de qualquer coisa, que, no entanto, sofre a 
força da possibilidade da pergunta "porquê?". Por este motivo, Leibniz, depois de enunciar o prs, acrescenta: "alioqui veritas daretur, quae non posset probari a priori (...), quod est contra naturam veritatis" (LEIBNIZ, 1961, p. 519; o sublinhado é meu). Quer dizer: se uma proposição é verdadeira, tal proposição é racional, quer dizer, o que nela se diz está constituído pela conexão ideal das suas várias partes (sujeito e predicado). E se há conexão ideal, é possível, pela consideração da ideia do sujeito, fazer derivar a presença nele do predicado, sem recurso à experiência. "É possível" de iure, isto, para quem conhece bem as coisas (para Deus, portanto): "principium omnis ratiocinationis primarium est, nihil esse <aut> fieri, quin ratio reddi possit, saltem ab omniscio, cur sit potius quam non sit, aut cur sic potius quam aliter, paucis Omnium rationem reddi posse" (LEIBNIZ, 1961, p. 25).

Ou seja: o mundo é dedutível a priori, ainda que apenas por Deus, que é o que significa a eliminação de toda a facticidade (prescinde-se aqui da extremamente complexa análise da diferença de modos de redução da facticidade). Quer dizer: Leibniz parece, afinal, não estar a adiantar muito mais do que a tese (que se aceitaria com facilidade) segundo a qual Deus (que não está sujeito à facticidade das coisas, que não necessita da experiência para as conhecer) fez as coisas "por algum motivo" e não "lançando os dados", com sabedoria e obedecendo à Sua própria racionalidade, e não por capricho cego ou arbitrário": "un de mes grands principes est que rien ne se fait sans raison. C'est un principe de philosophie. Cependant dans le fond ce n'est autre chose que l'aveu de la sagesse divine, quoyque je n'en parle d'abord" (LEIBNIZ, 1966, p. 58).

Mas o que parece estar em causa na discussão teológica não é tanto a causa Dei, mas o sentido mesmo do que entendemos por "ente" e por "diferença” (o que para nós é a mesma coisa), ou seja, o que parece estar em causa é a possibilidade de reconhecer algum sentido nesta história em que nos encontramos e nas coisas com que deparamos. Na verdade, se Deus é indiferente relativamente aos possíveis, este mundo enquanto é este mundo não tem nenhum interesse para Deus, o que do ponto de vista metafisico acaba por ter de reconhecer que se está no âmbito do insignificante arbitrário. Se Deus não tem em consideração aquilo que faz quando $o$ faz, passe a incorrecção do "quando", então aquilo que está feito está como se não estivesse, não tem mais significado que o oposto, é o tanto faz e não 
há absolutamente nada que se possa apresentar como justificação do que quer que seja, nem muita nem pouca.

Posto isto, resta a Leibniz extrair as conclusões que são, entre outras, as seguintes. Se a origem da determinação não pode estar na vontade, ela terá de estar forçosamente no intelecto. Mas não pode estar no intelecto enquanto este é indiferente aos possíveis que eventualmente considera, pois isso seria evidentemente devolver à vontade o papel de produzir a origem da determinação, o que se excluiu. $O$ que significa duas coisas: em primeiro lugar, que o intelecto não é nunca puramente especulativo, nenhum intelecto, nem mesmo, parece, o de Deus. Tal tese, que deixaria Duns Escoto perplexo, parece clara a Leibniz: se o intelecto de Deus fosse por essência especulativo seria indiferente aos possíveis, pois seria desinteressado, que é isso que significa ser "essencialmente especulativo". Como Leibniz afastou com repugnância essa tese indiferentista, não tem senão que ser consequente: o intelecto de Deus é essencialmente prático. Nós sabemos, ainda que só o saibamos a posteriori, que isso é assim, quer dizer, sabemos que a ciência que Deus tem dos possíveis é uma ciência prática, e sabemo-lo pela simples razão de que Deus fez coisas e fez coisas tendo em conta as coisas que fez: isso é precisamente ciência prática. A dizer verdade, o intelecto de Deus não é, como parece ser o nosso, prático por extensão, como dizia Aristóteles, quer dizer, que é imediatamente especulativo, mas que pode vir a ser prático. $\mathrm{O}$ caso de Deus parece ser diferente: o seu intelecto é originalmente prático, visto que Deus não tem em relação a nenhum dos possíveis, a absolutamente nenhum, uma atitude especulativa ou desinteressada. E isso é óbvio: se tivesse em relação a algum, não haveria razão para produzir o interesse prático em relação a quaisquer outros. É certo que Deus contempla os possíveis, mas contempla-os sempre como artista, como artesão, quer dizer, contempla-os sempre no acto de tomar o seu peso em relação à existência, em relação ao produto final acabado: "la sagesse de Dieu, non contente d'embrasser tous les possibles, les penetre, les compare, les pese les uns contre les autres, pour en estimer les degrés de perfection ou d'imperfection, le fort et le faible, le bien et le mal" (LEIBNIZ, 1978b, p. 252). Dito de outro modo, Deus não se limita a contemplar o que podia ou pode fazer, mas exerce sobre tudo o que contempla uma espécie de cálculo prático, com intenção de escolher o melhor, de fazer o melhor que pode fazer. O Deus de Leibniz é o oposto 
dos deuses de Aristóteles e de Epicuro. É um Deus que está essencialmente interessado em fazer. E, repete-se, nós (isto é, Leibniz) sabemos que é assim, porque de facto fez coisas, enquanto os de Aristóteles e Epicuro entretêm-se consigo próprios.

Em segundo lugar, a determinação do intelecto de Deus só pode provir do objecto, pelo que se disse: só o objecto diferencia o intelecto, o que implica que a origem do sentido e da determinação não pode deixar de residir na própria estrutura intrínseca dos possíveis, enquanto estão no intelecto divino ${ }^{11}$. Sobre esta segunda conclusão há, também, dois aspectos a ter em consideração. O primeiro é que, do ponto de vista da argumentação, ele é inevitável: a negação da liberdade de indiferença implica analiticamente que toda a determinação venha do objecto ${ }^{12}$. O segundo ponto é que, do ponto de vista teológico, a tese é muito duvidosa e Leibniz tem perfeita consciência disso. $\mathrm{Na}$ verdade, se o sujeito - divino ou não - é determinado pelo objecto, de modo a que a determinação possa ter origem, isso significa sempre uma certa passividade do intelecto - e, por maioria de razão, da vontade- relativamente ao objecto. A argumentação exige que o objecto possua uma determinação que lhe é própria e que seja essa determinação intrínseca que ponha em andamento a ponderação por parte do intelecto e a escolha por parte da vontade. Ou isto ou a indiferença. $\mathrm{Na}$ verdade, o intelecto só não seria passivo numa de duas possibilidades: ou seria puramente especulativo e a vontade seria, assim, absolutamente espontânea - é a tese de Duns Escoto - ou criaria ele próprio os possíveis, o que para Leibniz é impensável, pois isso seria criar a própria possibilidade, e não se percebe que é que isso pode querer dizer. Logo, o intelecto é passivo. E Leibniz admite-o, em certa medida, quando diz - e di-lo muitas vezes - que é a vontade que escolhe, e não o intelecto, e que a vontade se inclina ${ }^{13}$ (o termo já se encontrou em Duns Escoto). Aliás, é o próprio Deus que se inclina ${ }^{14}$. O conceito de inclinação é extraordinariamente comum em Leibniz e também é muito comum deixá-lo sem qualquer esclarecimento. Tanto quanto parece, inclinação significa que a vontade (pois é ela que se inclina) é determinada e especificada pelo objecto do intelecto em virtude da especificidade do objecto, pois de outra forma a inclinação seria arbitrária, pois o intelecto cairia, passe a expressão, para um dos possíveis por força da vontade arbitrária. Assim, a origem de todo o sentido está nos possíveis, isto é, na diferença intrínseca entre os 
possíveis, que, deste ponto de vista são totalmente independentes da vontade de Deus e também, em certo sentido, do seu intelecto, que se limita a encontrá-los lá: o intelecto de Deus não tem parte activa na constituição da diferença entre os possíveis. É claro que Leibniz poderá tentar mitigar a crueza da tese e dizer, com toda a tradição, que os possíveis se identificam com o próprio intelecto de Deus. Mas não é nada óbvio que isso resolva o problema, porque Deus não é chamado a intervir nem na constituição dos possíveis, nem no acto de preferir alguns deles, nem no acto de se inclinar para esses. A inclinação não depende do próprio "sujeito" Deus, passe a expressão. Dito de outro modo, o procedimento de constituição de toda a determinação, desde o princípio até ao produto final, isto é, até este mundo em que nos encontramos, é estrita e radicalmente natural ${ }^{15}$, isto é, anónimo e anonimamente espontâneo, e, diga-se de passagem, fora precisamente para evitar a concepção de um Deus deste estilo que Duns Escoto tinha vincado tão fortemente a natureza voluntária da escolha do mundo. Mas Leibniz já excluiu a tese da indiferença. Resta-lhe concluir que o Omnipotente só pode assistir ao que se passa naturalmente nEle, inclinar-se para os possíveis que naturalmente o seu intelecto prefere e escolher esses possíveis. É, aliás, sabido que Leibniz multiplica as metáforas, às vezes até cómicas, para descrever o acto em que o intelecto de Deus considera os possíveis, como se os possíveis se enchessem de adereços e de enfeites, para chamar a atenção do seu intelecto. Nalgum caso, por exemplo, fala de estátuas que cantam e dançam perante os deuses, para que estes decidam quais as que melhor cantam e dançam. Para além de todos estes adornos retóricos, o que parece, todavia, claro, é que tudo não passa de um processo puramente natural. A vontade divina deve escolher o possível que o intelecto preferiu; o intelecto prefere o possível que é mais perfeito que qualquer outro. A perfeição, por sua vez, pertence intrinsecamente ao possível e a regra de determinação de perfeição pertence naturalmente ao intelecto divino. Deus faz tudo sem ter que fazer o que quer que seja: a natureza age sábia a racionalmente $n E l e^{16}$. Deixa-se de lado, por agora, o problema da necessidade de todo este processo. O que está em causa aqui é o problema da determinação e só este. E o que interessa vincar é que, do ponto de vista da origem e constituição da determinação existente, o processo é todo puramente natural. Também aqui se aplica, portanto, aquela estranha exultação leibniziana do calculemos, neste caso, dito pelo intelecto de Deus. 
Daqui decorre também, como será talvez já claro, a razão pela qual Leibniz fala de uma pretensão para existir ${ }^{17}$ ou de um conatus ad existentiam por parte dos possíveis ${ }^{18}$. A tese é a de que os possíveis como que exercem uma força sobre Deus que O leva a dar-lhes existência. É claro que à primeira vista tudo não passaria de uma metáfora curiosa. A pretensão à existência, o esforço para existir, parece ser somente o próprio acto do cálculo dos possíveis por parte de Deus. Leibniz dirá, por isso, que um possível pretende tanto mais a existir quanto mais perfeição tiver e isso apenas quer dizer que o intelecto de Deus prefere o possível mais perfeito, como é próprio dos sábios. Quer dizer, parece que Leibniz está apenas a transferir para o objecto uma propriedade e um acto que pertencem ao sujeito que o considera. E neste sentido trata-se de uma pura figura de estilo. O que também parece ser o caso, na medida em que os possíveis se identificam com o intelecto divino. Mas, por outro lado, Leibniz parece ter toda a razão em atribuir essa propriedade aos próprios possíveis, pois é em virtude da estrutura formal dos possíveis que o intelecto prefere e que a vontade se inclina. Logo, a preferência do intelecto e a inclinação vontade têm origem neles, na própria estrutura dos possíveis. O conatus deve, pois, corresponder a algo nos possíveis, pelo menos a sua perfeição formal intrínseca, dada num intelecto prático. De facto, é precisamente porque o intelecto é prático que há preferência e conatus. Mas, por outro lado, o intelecto prático é especificado pelo próprio objecto, é ele que determina a inclinação e, neste sentido, o conatus pertence realmente aos possíveis. Isto é, para falar com os escolásticos, quoad specificationem o conatus pertence aos possíveis e não ao intelecto ${ }^{19}$. Também por isso se compreende muito bem a insistência leibniziana em falar dos possíveis na forma do particípio futuro e de determinar como propriedade formal da possibilidade a existiturientia, isto é, a propriedade de ser o que há-de vir a ser ${ }^{20}$. Os possíveis não são, por isso, meras determinações negativas neutras, simples ausência de contradição. Pelo contrário, possível é o que "há-de vir a ser" e a definição de possível não é lógica, mas inclui, por isso, a própria noção de existência, no caso de haver tal noção.

Esta tese poderia parecer inofensiva, dado que os possíveis são no intelecto divino. Mas há aqui, parece, uma originalidade leibniziana que deve ser assinalada. Segundo a tradição, os possíveis são objecto apenas secundário do intelecto divino, pois o objecto primário é o próprio Deus. Os 
possíveis seriam, ainda de acordo com a tradição, a compreensão que Deus tem de si mesmo enquanto participável pelo finito. Esta tese é a comum na escolástica ${ }^{21}$. Ora tudo leva a crer que, segundo Leibniz, os possíveis são também objecto primário do intelecto divino e assim deve, na verdade, ser, se o seu intelecto é prático ${ }^{22}$. $\mathrm{Na}$ verdade, toda a argumentação leibniziana depende desta tese, pois é por isso e só por isso que este é o melhor dos mundos possíveis e que Deus não pode ser acusado do mal que nos toca. De facto, Leibniz repete que Deus se negaria a Si próprio se não fizesse o melhor, e isso é assim porque não fazer o melhor, podendo, é a mesma coisa que fazer algo mal ou mau. Em certo sentido, e concretamente neste, um bem menor perante um bem maior possível é certamente um mal ${ }^{23}$. Logo, este mundo é o melhor. Leibniz, então, terá de provar que a noção de melhor mundo possível não é contraditória. Se fosse, criar-se-ia em Deus um curioso caso de dilema moral, porque ele faria mal em qualquer dos casos, o que os antigos chamavam um caso de "consciência perplexa". Leibniz sabe que não é assim, quer dizer, sabe que há mesmo um mundo melhor, pela simples razão de haver um real. Mas não é este agora o problema. O problema é, antes, este. A tradição dizia que só se pode falar em mal na presença de um bem devido. Neste sentido, como Deus não está em situação de débito relativamente a qualquer determinação finita, não faria mal nenhum criando um mundo que não fosse o melhor, porque o melhor não era devido. Ora Leibniz diz expressamente que Deus deve algo aos possíveis porque o deve a Si próprio - "mais Dieu manqueroit à ce qui est dû à l'univers, c'est à dire à ce qu'il doit à soy même (LEIBNIZ, 1978 b, p. 172 $)^{24}$-, o que só pode mesmo significar que por intelecto divino Leibniz entende rigorosamente a região dos possíveis, e por Deus o âmbito prático da produção da existência. Se assim não fosse, Leibniz não poderia identificar o que Deus deve a Si e o que deve aos possíveis. $\mathrm{Ou}$ seja, não se trata de que o ser da possibilidade seja Deus, o que qualquer crente aceitará sem problema. Trata-se de que por Deus se entende rigorosamente o "vir a ser da possibilidade", o que é totalmente diferente.

Deve ter-se em conta, todavia, que há ainda um problema - e um problema central - que não foi sequer resolvido, que é, afinal, o problema do potius, da preferência. Na verdade, o problema da preferência não é o da diferença, pois esta é somente a pressuposição da preferência. É evidentemente necessário que umas coisas sejam diferentes das outras para que 
umas sejam preferíveis as outras. Mas é preciso, de e de um modo também evidente, algo mais. É preciso que algo seja melhor e melhor é mais do que diferente. Ora este é que é essencialmente o núcleo da noção de razão suficiente, pois o potius aparece sempre junto do princípio. Que é que torna, afinal, uma coisa preferível? E é curioso que Leibniz quase sempre reduz o problema da preferência ao problema da diferença. Mas, insiste-se, são dois assuntos diferentes. O problema resolver-se-ia se a preferência se devesse a idiossincrasias do sujeito, sejam elas quais forem. Mas isso já foi excluído, porque introduziria sub-repticiamente a liberdade de indiferença, isto é, a negação da diferença entre ser e não ser. $\mathrm{O}$ que significa que os objectos devem estar determinados no seu próprio acontecimento ôntico de modo a que uns sejam preferíveis a outros. E não é claro a que é que corresponde o fundamento dessa diferença. Não é possível examinar aqui a difícil questão do potius. Mas vale a pena fazer referência à Carta de Leibniz a Magnus Wedderkopf onde o problema é enfrentado directamente. Diz assim: "quae ergo ultima ratio voluntatis divinae? intellectus divinus. Deus enima vult quae óptima item harmonicotata intelligit eaque velut seligit ex numero omnium possibilium infinito. Quae ergo intellectus divini? harmonia rerum. Quae ergo harmonia rerum? nihil" (LEIBNIZ, 2006, p. 186). Tal como não é possível examinar a questão do potius, não é igualmente possível examinar a da harmonia. De um modo muito geral, pode dizer-se que a harmonia corresponde à noção de sistema, no sentido técnico do termo - isto é, ao acontecimento de "tudo em tudo", que tanto admirava Leibniz - e que esse acontecimento é preferível por razões matemáticas, isto é, pelo facto de unir o máximo de determinação com o mínimo de requisitos. É certo que, pelo menos para nós, não é ainda claro porque é que isso é preferível ou, o que é dizer a mesma coisa, que essa preferência parece meramente estética. Mas o que o texto de Leibniz citado parece querer dizer é que não há razão para que a preferência seja desta ordem e isso pode ser interpretado de dois modos, pelo menos: ou que o potius está, em última análise, fundado num facto, quer dizer, que o princípio de razão sofre ele próprio de uma facticidade não justificada; ou, é a hipótese mais benigna, que a harmonia é a definição real e a única possível de preferência, que dizer, não só do que chamamos razão, mas do que é, em si e absolutamente, razão, mesmo que, para nós, a apresentação disso não escape à facticidade. 
${ }^{1}$ Sobre a justiça como atributo próprio de Deus, cfr., por exemplo, LEIBNIZ, 1978b, p. 51 e 70 (onde se afirma ainda que "le droit universel est le même pour Dieu et pour les hommes"), p. 71-72 ("il ne faut pas dire non plus, que ce que nous appellons justice, n’est rien par rapport à Dieu (...), ou enfin que le justice est quelque chose d'arbitraire à son égard”), pp. 144, 219-220 (texto especialmente claro), etc. Em geral, as referências de Leibniz serão feitas principalmente a esta obra, dada a sua natureza paradigmática relativamente ao problema em causa.

2 Os textos da Suma Teológica mais directamente relevantes para este tema são: S. Th., I, q. 19, a. 2 ; q. 21 , a. 1 ; q. 25 , a. 5 .

${ }^{3}$ A referência completa é Ordinatio, IV, d. 46, q. 1, n. 24. Sempre que possível citar-se-á o texto segundo a edição dita Vaticana. Quando assim não for, segue-se o texto da edição Wadding.

${ }^{4}$ No que diz respeito a Tomás de Aquino, vejam-se as passagens citadas na nota 2.

${ }^{5}$ Veja-se a análise da noção de possibilidade em DUNS ESCOTO, 1966, na d. 43.

6 “Quod intellectus apprehendit agibile, antequam voluntas illud velit, sed non apprehendit determinate hoc esse agendum, quod apprehendere dicitur dictare; imo, ut neutrum est, offert voluntati divinae, qua determinate per volitionem suam illud esse agendum, intellectus apprehendit tanquam verum illud agendum" (DUNS ESCOTO, 2001). A referência completa é Ord., IV, d. 46, q. 1, n. 37.Veja-se também DUNS ESCOTO, 1994, q. 5, n. 44: "Unde quando intellectus divinus apprehendit 'hoc esse faciendum' ante voluntatis actum, apprehendit ut neutram, sicut cum apprehendo 'astra esse paria",

${ }^{7}$ Veja-se o texto explícito em DUNS ESCOTO, 1994, q. 5. n. 43: “in Deo non est scientia practica, quia si ante actuam voluntatis intellectus apprehenderet aliquid esse operandum aur producendum, voluntas igitur vult necessário aut non? Si necessário, igitur necessitatur ad producendum illud; si non necessario vult, igitur vult contra dictamen intellectus, et tunc esset mala, cum illud dictamen non potest esse nisi rectum”.

8 “... c'est proprement detruire la justice de Dieu; car quelle notion assignerons nous à une telle espece de justice, qui n'a que la volonté pour regle, c'est à dire, où la volonté n'est pas dirigée par les regles du bien, et se porte meme directemente au mal?”, LEIBNIZ, 1978b, p. 35.

${ }^{9}$ Cf., só a titulo de mero exemplo, a possibilidade de comparar Deus a Calígula (LEIBNIZ, 1978b, p. 209).

${ }^{10} \mathrm{~A}$ referência é à questão 16.

11 "il faut que la cause du monde ait eu egard ou relation à tous ces mondes possibles, pour en determiner un. Et cet egard ou rapport d'une substance existante à des simples possibilites, ne peut être autre chose que l'entendement qui en a les idées", LEIBNIZ, 1978b, p. 106.

${ }^{12}$ Leibniz admite expressamente que a consideração do objecto é determinante na razão da escolha de Deus. Cf. LEIBNIZ, 1978b, pp. 160, 163. Veja-se, a este respeito, um texto claramente anti-escotista nas páginas 218-219: “quel sujet pourroit en avoir de le (a Deus) louer de ce qu'il a fait, s'il avoit fait egalemente bien en faisant toute autre chose?”.

13 Cf., por exemplo, LEIBNIZ, 1978b, pp. 115-116, 128.

${ }^{14}$ Cf. LEIBNIZ, 1978b, p. 424.

doispontos, Curitiba, São Carlos, vol. 11, n. 2, p.99-130, outubro, 2014 
15 “Ce pretendu fatum, qui oblige même la Divinité, n'est autre chose que la propre nature de Dieu, son propre entendement (...); c'est une heureuse necessite, sans laquelle il ne seroit ny bon ny sage", LEIBNIZ, 1978b, p. 230.

${ }^{16}$ Veja-se uma explicação quase mecânica do processo de escolha dos possíveis em LEIBNIZ, 1978b, pp. 116, 145-146, 169-170,

${ }^{17}$ Sobre a pretensão à existência, veja-se LEIBNIZ, 1978b, pp. 106, 236, por exemplo.

18 O texto mais célebre diz: "sed quae causa facit ut aliquid existat, seu ut possibilitas exigat existentiam, facit etiam ut omne possibile habeat conatum ad Existentiam, cum ratio restrictionis ad certa possibilita in universal repetiti non possit" ( LEIBNIZ, 1961, p. 534).

${ }^{19}$ Veja-se resumo das diferentes opiniões sobre a interpretação do conatus em JEANGENE VILMER, J.-B., 2006.

${ }^{20}$ O texto quase canónico em LEIBNIZ, 1999, pp. 1634-1635. O texto é comentado por ROBINET, A., 2004. Não é possível discutir aqui as teses de Robinet.

${ }^{21}$ Cfr. p. ex., em Tomás de Aquino, o cap. 29 do Livro da Summa contra Gentes.

22 “Je ne sais s'il y a peutêtre encor des gens, qui s'imaginent que Dieu étant le maitre absolu de toutes choses, on en peut inferer que tout ce qui est hors de luy, luy est indiferent; qu'il s'est regardé seulement soy même, sans se soucier des autres (...). Mais enseigner cela de Dieu, ce seroit luy ôter la sagesse et la bonté” (LEIBNIZ, 1978b, p. 145).

23 "Car comme un moindre mal est une espece de bien, de même un moindre bien est une espece de mal, s'il fait obstacle a un bien plus grand” (LEIBNIZ, 1978b, p. 107).

${ }^{24}$ Cf. ainda LEIBNIZ 1978b, p. 117: “il (Deus) manqueroit à ce qu'il se doit, à ce qu'il doit à as sagesse, à sa bonté, à sa perfection, s'il ne suivoit pas le grand resultat de toutes ses tendences au bien, s'il ne choisissoit pas ce qui est absolument le meilleur".

\section{Referências bibliograficas}

DUNS ESCOTO, I. 1966. Lectura in Librum Primum Sententiarum.

Distinctiones 8-45, in Opera Omnia, Civitas Vaticana, Typis Vaticana, vol. XVII.

DUNS ESCOTO, I. 1994. Contingency and Freedom. Lectura I, 39.

Int., trad. e com. porVOS JACZN, A.,VELDHUIS, H., LOOMAN-

GRAASKAMP, A., DEKKER, E e DEN BOK, N., Dordrecht, Kluwer.

DUNS ESCOTO, I. 2001. Opera Omnia. Editio Minor (ed.

LAURIOLA, G. ), vol. III, Alberobello, Ed. Aga.

JEANGENE VILMER, J.-B. 2006. Possibilité et existentiabilité chez Leibniz, Revue Philosophique de Louvain, 104 (1), pp. 23-45. 
LEIBNIZ, G. W. 1961. Opuscules et Fragments Inédits, ed. L.

COUTURAT, Hildesheim, Georg Olms Verlag, , reimp.

LEIBNIZ, G. W. 1966. Die Leibniz-Handschriften der Königlichen öffentlichen Bibliothek zu Hannover, ed. E. Bodemann, Hildesheim, Georg Olms Verlag, reimp.

LEIBNIZ, G. W. 1978a. Principes de la Nature et de la Grace, fondés en raison, in Die philosophischen Schriften, vol. 6, Hildesheim, Georg Olms Verlag, reimp.

LEIBNIZ, G.W. 1978b. Essais de Théodicée, in Die philosophischen Schriften, vol. 6, Hildesheim, Georg Olms Verlag, reimp.

LEIBNIZ, G. W. 1981. Confessio Philosophi, in Sämtliche Schriften und Briefe, ed. Deutschen Akademie der Wissenschaften zu Berlin, Berlin, Akademie Verlag,VI, III.

LEIBNIZ, G.W. 1999. De Ratione Cur Haec Existant Potius Quam Alia, in Sämtliche Schriften und Briefe, ed. Deutschen Akademie der Wissenschaften zu Berlin, Berlin, Akademie Verlag,VI, IV.

LEIBNIZ, G. W. 2006. Philosophischer Briefwechsel, in Sämtliche Schriften und Briefe, ed. Deutschen Akademie der Wissenschaften zu Berlin, Berlin, Akademie Verlag, II, I.

OCKHAM, G. 1980. Quodlibeta Septem in Opera Philosophica et Theologica, vol. IX, Saint Bonaventure (N.Y.), St. Bonaventure University Press.

PARFIT, F. 2011. On What Matters, Oxford, Oxford University Press, vol. I.

ROBINET, A. 2004. Le Sera, Paris, Vrin. 